\title{
Genetic differentiation, origin and dispersal of Gammarus gauthieri from the Iberian peninsula and North Africa (Crustacea, Amphipoda)
}

\author{
Maarten Scheepmaker \\ Institute of Taxonomic Zoology, University of Amsterdam, P.O. Box 4766, 1009 AT Amsterdam, \\ The Netherlands
}

Keywords: Distribution, Genetic divergence, Gene flow, Molecular clock, Gammarus

\begin{abstract}
Genetic differentiation among population samples of $G$. gauthieri on both sides of the Strait of Gibraltar was investigated by enzyme electrophoresis at 20 enzyme loci with reference to $G$. gauthieri and $G$. ibericus from different areas in the lberian peninsula.

Levels of divergence resolved suggest that $G$. gauthieri reached North Africa from the Iberian peninsula, and not vice versa. With reference to geological evidence, this was likely to occur during the Messinian (6-5 My ago). As the opening of the Strait of Gibraltar represents a well dated geological event, an attempt has been made to calibrate the molecular clock for the G. pulex-group.

Indirect estimations of gene flow levels were shown to be extremely low. Probably as a consequence of frequently occurring semi-arid conditions, populations of $G$. gauthieri are strongly subdivided and likely to be subject to stochastic processes. Therefore, even within areas, population samples may be genetically markedly different.

Dendrograms of genetic distances were compared with geological evidence. From these data an hypothesis of phylogenetic relationships is proposed.
\end{abstract}

\section{Résumé}

La différentiation génétique entre des prélèvements de populations de $G$. gauthieri de chaque côté du détroit de Gibraltar, par rapport à $G$. gauthieri et $G$. ibericus issus de différentes régions de la Péninsule Ibérique, a été étudiée par électrophorèse à 20 loci d'enzymes.

Les niveaux de divergence observés suggèrent que G. gauthieri a gagné l'Afrique du Nord à partir de la Péninsule Ibérique, et non pas vice versa. Compte tenu des données géologiques, cela se serait produit pendant le Messinien (il y a 6-5 Ma). Puisque l'ouverture du détroit de Gibraltar représente un événement géologique bien daté, un essai a été fait de calibrer l'horloge moleculaire pour le groupe $G$. pulex.

Des estimations indirectes des niveaux de flux génétique se sont montrées extrêmement basses. Probablement à la suite des conditions de semi-aridité intervenant fréquemment, les populations de $G$. gauthieri sont fortement subdivisées et susceptibles d'être soumises à des processus stochastiques. De ce fait, des prélèvements de populations peuvent être génétiqement remarquablement différents, même à l'intérieur d'une même région.

Des dendrogrammes de distances génétiques ont étés mises en rapport avec des faits géologiques. A partir de ces données, une hypothèse des relations phylogénétiques est proposée.

\section{Introduction}

The Iberian members of the Gammarus pulexgroup (sensu Karaman \& Pinkster, 1977) $G$. gauthieri S. Karaman, 1935 and G. ibericus Margalef, 1951 were shown to be genetically very distinct from taxa of this group from north of the Pyrenees. According to Scheepmaker et al., (1988), with reference to other species, genetic differentiation between French and Iberian species was observed at the generic level. As the freshwater fauna of the Iberian peninsula is related to that of North Africa, Scheepmaker et al. (1988) suggested the possibility that Iberian members of the $G$. pulexgroup originate from forms in North Africa, and not from the closely related forms from western Europe north of the Pyrenees. Although G. gauthieri is distributed in Spain, Morocco, Algeria and Tunisia, it is not clear whether it reached Morocco from the Iberian peninsula or vice versa (Scheepmaker et al., 1988). G. ibericus is endemic for the 
Table I. Sampling localities and species distribution.

\begin{tabular}{|c|c|c|c|c|c|c|c|}
\hline $\begin{array}{l}\text { Station } \\
\text { no. }\end{array}$ & $\begin{array}{l}\text { Area in } \\
\text { fig. } 1 \mathrm{~A}, \mathrm{~B}\end{array}$ & Species & Country & Prov /dept & $\begin{array}{l}\text { Drainage } \\
\text { system }\end{array}$ & Locality description/reference & $\begin{array}{r}\text { Sampling } \\
\text { date }\end{array}$ \\
\hline 1 & - & G. d. duebeni & Holland & North-Holland & - & $\begin{array}{l}\text { Brackish pool behind the dikes of the Hondsbosche } \\
\text { Zeeweering at Petten, westside of the Vereenigde } \\
\text { Harger- and Pettemerpolder, near road N9 }\end{array}$ & 3-VII-'88 \\
\hline 2 & $\cdot$ & G. d. duebeni & France & Pas-de-Calais & - & $\begin{array}{l}\text { Rockpool along the coast at Audresselles, near } \\
\text { road D } 940\end{array}$ & 24-VII-'88 \\
\hline 3 & C & G. d. celticus & France & Finistère & La Flóche & At the crossing with road D788, $1.5 \mathrm{~km}$ E. of Lesneven & 25-VII-"88 \\
\hline 4 & $\mathbf{C}$ & G.d. celticus & France & Finistère & Elom & $\begin{array}{l}\text { Tributary, at the municipal camping of Sizun, near } \\
\text { road D764 }\end{array}$ & 25-VII-'88 \\
\hline 5 & - & G. gauthieri & Morocco & Marrakech & Oued Aouri & $\begin{array}{l}\text { Source at Imi-n-Tala, at the end of a mountain track } \\
7 \mathrm{~km} \mathrm{~S} \text {. of Amizmiz and road S507 }\end{array}$ & 23-III-'88 \\
\hline 6 & D & G. gauthieri & Morocco & Khenifra & - & $\begin{array}{l}\text { Stream draining directly in the Aguelmane de Sidi Ali, } \\
\text { near road } 3211,20 \mathrm{~km} \mathrm{S.} \mathrm{of} \mathrm{Timhadite}\end{array}$ & 23-III-'88 \\
\hline 7 & D & G. gauthieri & Morocco & Khenifra & Oued Beth & $\begin{array}{l}\text { Ain Achbal, source of the Tigrigra tributary, } 2 \mathrm{~km} \mathrm{~W} \text {. of } \\
\text { Azrou, near road P24 }\end{array}$ & 24-HII-'88 \\
\hline 8 & D & G. gauthieri & Morocco & Khenifra & Oued Sebou & $\begin{array}{l}\text { Oued Mikkès, tributary alongside road S309, } 3 \mathrm{~km} \text { S.E. } \\
\text { of Ifrane }\end{array}$ & 24-III-'88 \\
\hline 9 & D & G. gauthieri & Morocco & Khenifra & Oued Sebou & $\begin{array}{l}\text { Tributary at the crossing with road } 4629,10 \mathrm{~km} \text { S.S.E } \\
\text { of Imouzzèr-du-Kandar }\end{array}$ & 24-III-'88 \\
\hline 10 & $\mathbf{E}$ & G. gauthieri & Spain & Ronda & Río Guadiaro & $\begin{array}{l}\text { Río Guadalobacin, tributary crossing road } 420 \text {, } \\
1.5 \mathrm{~km} \mathrm{~N} \text {. of Ariate }\end{array}$ & 26-III-'88 \\
\hline 11 & $\mathbf{E}$ & G. gauthieri & Spain & Ronda & Río Guadalhorce & $\begin{array}{l}\text { Río de las Cuevas, near road C341, } 0.5 \mathrm{~km} \text { E. of } \\
\text { Cuevas del Becerro }\end{array}$ & 27-III-'88 \\
\hline $\mathbf{a}$ & $\begin{array}{l}\mathbf{F} \\
\mathbf{F}\end{array}$ & $\begin{array}{l}\text { G. gauthieri } \\
\text { G. gauthieri }\end{array}$ & $\begin{array}{l}\text { Spain } \\
\text { Spain }\end{array}$ & $\begin{array}{l}\text { Cuenca } \\
\text { Cuenca }\end{array}$ & $\begin{array}{l}\text { Tajo } \\
\text { Guadiana }\end{array}$ & $\begin{array}{l}\text { Station } 6 \text { in Scheepmaker et al. (1988) } \\
\text { Station } 7 \text { in Scheepmaker et al. (1988) }\end{array}$ & - \\
\hline c & $\begin{array}{l}\mathbf{G} \\
\mathbf{G}\end{array}$ & $\begin{array}{l}\text { G. gauthieri } \\
\text { G. gauthieri }\end{array}$ & $\begin{array}{l}\text { Spain } \\
\text { Spain }\end{array}$ & $\begin{array}{l}\text { Valladolid } \\
\text { Valladolid }\end{array}$ & $\begin{array}{l}\text { Duero } \\
\text { Duero }\end{array}$ & $\begin{array}{l}\text { Station } 10 \text { in Scheepmaker et al. (1988) } \\
\text { Station } 11 \text { in Scheepmaker et al (1988) }\end{array}$ & - \\
\hline e & $\mathbf{G}$ & G. gauthieri & Spain & Valladolid & Duero & Station 12 in Scheepmaker et al. (1988) & - \\
\hline $\mathbf{f}$ & $\mathbf{F}$ & G. ibericus & Spain & Cuenca & Jucar & Station 8 in Scheepmaker et al. (1988) & \\
\hline g & $\mathbf{F}$ & G. ibericus & Spain & Cuenca & Tajo & Station 9 in Scheepmaker et al. (1988) & - \\
\hline
\end{tabular}

Serranía de Cuenca, a mountainous area in central Spain (Lop, 1987).

The present study investigates the possible origins of G. gauthieri and G. ibericus. Primarily, genetic relationships among $G$. gauthieri populations from North Africa and the Iberian peninsula on either side of the Strait of Gibraltar are studied with reference to levels of divergence among populations of $G$. gauthieri and $G$. ibericus resolved within the Iberian peninsula by Scheepmaker et al. (1988). Intra-specific genetic differentiation was examined in relation to estimated levels of gene flow. As indices of gene flow based on $F$-statistics may be influenced by natural selection and therefore may constitute poor indicators of the genetic structure of populations, these indices were used in combination with the methods of Slatkin $(1981,1985)$; the latter methods are believed to be less sensitive to the influence of natural selection (Barton \& Slatkin, 1987).

On the other hand, divergence data and phylo- genetic relationships are compared with geological evidence. The most obvious and recent migratory pathway between the Iberian peninsula and North Africa is across the Strait of Gibraltar (e.g. Busack, 1986, Scheepmaker et al., 1988). Extension of $G$. gauthieri may have occurred during the Messinian salinity crisis, when the Mediterranean dried up (6-5 My ago; e.g. Hsü et al., 1977). However, the complexity of the paleogeography of the western Mediterranean (e.g. Dercourt et al., 1985; Maldonado, 1985) is an obstacle to any a priori assumption concerning the distributional history of $G$. gauthieri. Therefore, other hypotheses of dispersal or vicariant events leading to its present distribution should not be discarded.

It may be justified to calibrate the molecular clock for a given set of loci in a group of closely related species, as long as the evolutionary rates for the individual loci remain constant (Scheepmaker et al., 1988). As the results of this study are in favour of a Messinian extension across the Strait of Gibral- 

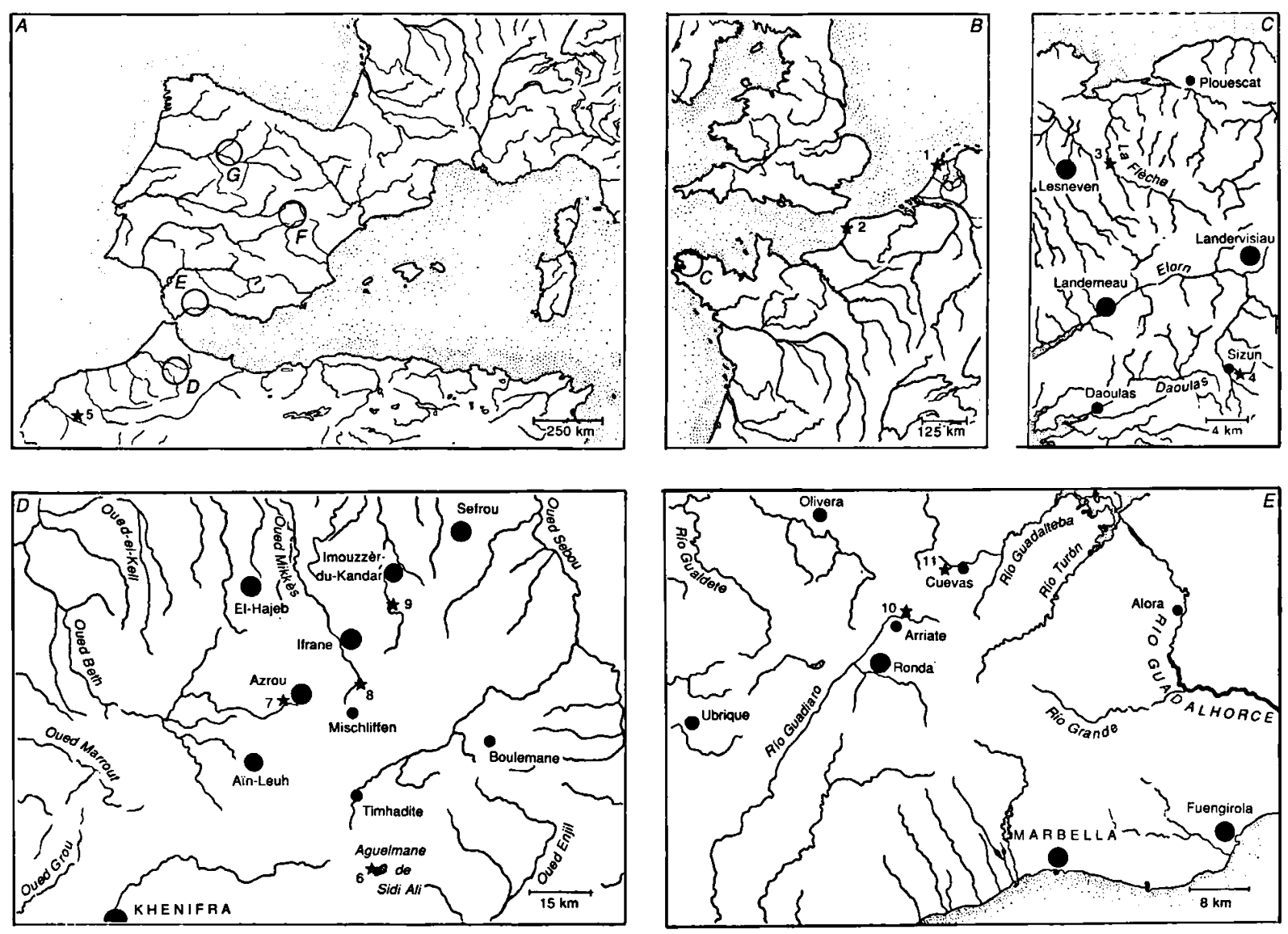

Fig. IA-E. Study areas and sampling localities (cf. Table I).

tar, an attempt was made to provide an initial calibration of the molecular clock for the $G$. pulex-group.

Genetic variation at 20 presumptive enzyme loci was investigated using starch gel electrophoresis. A network of phylogenetic relationships was rooted by the outgroup method (Farris, 1972). In addition to Scheepmaker et al. (1988), hybridization experiments among samples of $G$. gauthieri from Morocco and the Iberian peninsula were carried out to evaluate the taxonomic status of the forms involved, and the evolutionary significance of the genetic variation recorded. From these data, an evolution model of $G$. gauthieri in the western Mediterranean area is proposed.

\section{Materials and methods}

\section{Sampling and collection sites}

Sampling for electrophoretic studies and crossbreeding experiments was carried out based on the procedures of Scheepmaker (1987). The collection sites and sampling dates along with the species collected are listed in Table I and Figs. 1A-E. In Morocco, the area closest to the Strait of Gibraltar from which gammarids were reported, was sampled at four localities to evaluate local genetic variation (the Khenifra area: Fig. 1A, area D; Table I and Fig. 1D, stations 6-9). One of these localities (station 6) is the type locality of $G$. acalceolatus Pinkster, 1971 (a form morphologically very similar to G. ibericus, but calceoli are lacking). However, only G. gauthieri was sampled at this locality. To 
evaluate geographic variation over greater distances, one sample in the High Atlas was taken (Table I, Fig. 1A; station 5). In Spain, the area closest to the Strait of Gibraltar from which gammarids are known is the province Ronda (Table $I$, Figs. 1A, E, area E; stations 10-11). In that area, due to an increased pollution of most tributaries, not more than two localities could be sampled. For purposes of outgroup comparison, two samples of the marine and brackish form $G$. duebeni duebeni Liljeborg, 1852 (Table I, Fig. 1A; stations 1-2), and two samples of the freshwater form $G$. duebeni celticus Stock \& Pinkster, 1970 (Table I, Fig. 1B, C, area $C$; stations 3-4) were studied simultaneously.

\section{Electrophoresis}

Electrophoresis and staining procedures were identical to those of Scheepmaker et al. (1988). The following enzyme systems were assayed (E. C. numbers between parentheses): ADA-Adenosine deaminase (3.5.4.4); ALP - Alkaline phosphatase (3.1.3.1); APK-Arginine phosphate kinase (2.7.3.3); EST-Esterase (3.1.1.1); GDH - Glutamate dehydrogenase (1.1.1.47); GOT-Glutamic oxaloacetic transaminase (2.6.1.1); GPI Glucose phosphate isomerase (5.3.1.11); HKHexokinase (2.7.1.1); LAP - Leucine aminopeptidase (3.4.1.1); MDH - Malate dehydrogenase (1.1.1.37); ME - Malic enzyme (1.1.1.40); MPI Mannose phosphate isomerase (5.3.1.8); PEP Peptidase (3.4.11/13); 6PGD-6 Phosphogluconate dehydrogenase (1.1.1.44); PK - Pyruvate kinase (2.7.1.40).

\section{Analysis of allozyme variation}

The genetic interpretation of the variation was inferential. Data were analyzed by the computer program BIOSYS-1 (Swofford \& Selander, 1981). A matrix of Nei's (1972) genetic distance $(D)$ was calculated for all populations sampled for this study, and for G. gauthieri and G. ibericus from the Iberian peninsula sampled by Scheepmaker et al. (1988). From these data (for sake of space not all presented here), an UPGMA dendrogram (Sneath \& Sokal, 1973) was constructed. A "character state" transformation scheme was generated with the aid of the program Jelly (Ellis, 1987). The Jelly network generates ancestors (Hypothetical Taxonomic Units or HTU's) with their own gene frequencies (thus not selected from one of the states occurring in the Operational Taxonomic Units or OTU's) that sum up to one using Rogers' (1984) HAP algorithm; for a discussion of this method see Scheepmaker et al. (1988).

The UPGMA method and Nei's (1972) distance coefficient require both the assumption of homogeneous evolutionary rates (e.g. Farris, 1981). Moreover, Nei's distance is unsuitable for deriving phylogenies because of its non-metricity. The Jelly network does not require any assumption about evolutionary rates. Rooted by the outgroup method, this procedure seems more appropriate to infer phylogenetic relationships; however, the choice of an outgroup taxon is not directly obvious. Although genetically distant and reproductively isolated from G. gauthieri and G. ibericus (Scheepmaker et al., 1988), members of the G. pulex-group in northwestern Europe are genetically less differentiated, suggesting a more recent origin. Therefore, they may not represent a suitable outgroup. On the other hand, related forms may be genetically so dissimilar, that they do not contribute to resolve phylogenetic relationships (e.g. Skadsheim \& Siegismund, 1986). Genetically as well as morphologically, G. duebeni (i.e. G. d. duebeni $+G$. d. celticus) appears to be sufficiently distinct from the ingroup to meet the requirements of an outgroup without being too different. The state of several taxonomically important characters in $G$. duebeni is intermediate between that encountered in the $G$. pulex-group and in the systematically distinct brackish and marine forms like G. zaddachi Sexton, 1912 and G. salinus Spooner, 1947 (viz. protruding lobe backwards of basipodite P5-7, setation and armature P3-7, setal fringe of the mandibular palp, and shape of the eye; Karaman \& Pinkster, 1977; Lincoln, 1979; Gledhill et al., 1976; Pinkster \& Platvoet, 1986). G. duebeni is commonly assumed to be old and formerly widespread in western Europe (e.g. Hynes, 1954, 1955; Pinkster 
Table II. Electromorph frequencies at 17 presumptive gene loci. $d=G$. d. duebeni; $c=G$. d. celticus; $g=G$. gauthieri; $\mathrm{N}=$ sample size; $h=$ heterozygosity per locus (direct count); $H=$ mean heterozygosity over all (including monomorphic) loci; * = significant departure from Hardy-Weinberg distribution $(P<0.05)$; electromorph designation from fastest to slowest in alphabetical order, in accordance with Scheepmaker \& Van Dalfsen (1989) and Scheepmaker (1989); alternative allelic designations employed by Scheepmaker et al. (1988) are given in parentheses.

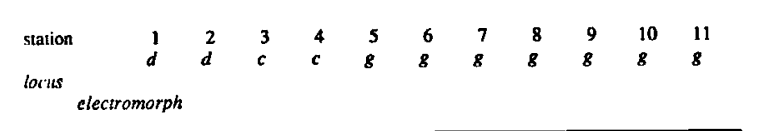

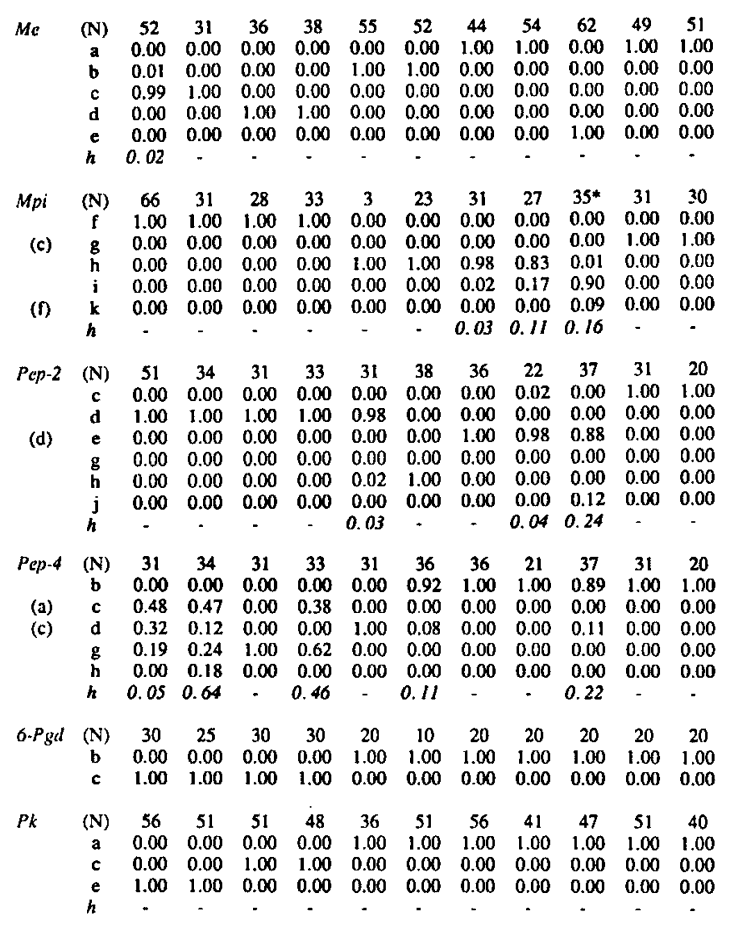

$\begin{array}{llllllllllll}H & 0.04 & 0.06 & 0.01 & 0.07 & 0.02 & 0.02 & 0.04 & 0.03 & 0.10 & 0.03 & 0.04\end{array}$

et al., 1970; Golikov \& Tzvetkova, 1972); compared with members of the $G$. pulex-group as well as with $G$. zaddachi and $G$. salinus, reproduction occurs at a slow rate which is considered a primitive character by Pinkster (pers. comm.).

To measure population subdivision, $F$-statistics $(\theta)$ were calculated according to Weir $\&$ Cockerham (1984). For loci with multiple alleles, a weighted average $\theta$ was calculated. Significance of the observed $\theta$-values was tested with a chi-square heterogeneity test (Workman \& Niswander, 1970). Gene flow estimates $(\mathrm{Nm})$ were derived from the relation$\operatorname{ship} \theta=1 / 1+4 N m$, where $N$ is the effective population size and $m$ the migration rate (Wright, 1931). $\theta$ - and $N m_{\theta}$-values were calculated with the aid of the program Thèta (Ellis, 1989).

Gene flow levels $(\mathrm{Nm})$ among populations and areas were also calculated from the average frequency of private alleles $\bar{p}$ (1) according to Slatkin (1985). To adjust for differences in sample size, a corrected $\mathrm{Nm}$-value, $\mathrm{Nm}^{*}$, is obtained by dividing the $N m$ estimate by the ratio of the actual sample 
Table III. Number of diagnostic loci ( 0.99 criterion; Ayala \& Powell, 1972) among samples of the populations studied, averaged by area. Data from Scheepmaker et al. (1988) are included.

\begin{tabular}{|c|c|c|c|c|c|c|c|c|c|c|c|c|}
\hline spocies & $\begin{array}{l}\text { wrea/ } \\
\text { aution(s) }\end{array}$ & $\begin{array}{l}\text { no. of } \\
\text { semples }\end{array}$ & 1,2 & C; 3,4 & 5 & D: 6 & D: 7,8,9 & $E ; 10.11$ & F: a, b & G; c,d,e & $F ; f$ & $F: 8$ \\
\hline G.d. duebeni & 1.2 & 2 & - & & & & & & & & & \\
\hline G.d. cebicises & $C ; 3,4$ & 2 & 2 & - & & & & & & & & \\
\hline G. gauthieri & 5 & 1 & 10 & 12 & - & & & & & & & \\
\hline G. gaunhieri & $D ; 6$ & 1 & 11 & 14 & 1 & - & & & & & & \\
\hline G. gavothieri & D; $7,8,9$ & 3 & 9 & 13 & 3 & 3 & $\cdot$ & & & & & \\
\hline G. gawhieri & $E ; 10,11$ & 2 & 11 & 13 & 8 & 7 & 4 & - & & & & \\
\hline G. gawthieri & $\mathbf{F} ; \boldsymbol{m}, \mathbf{b}$ & 2 & 12 & 14 & 7 & 5 & 3 & 5 & - & & & \\
\hline G. gavahieri & G; c,d,e & 3 & 11 & 12 & 9 & 6 & 2 & 8 & 9 & - & & \\
\hline G. ibericus & $P ; f$ & 1 & 12 & 12 & 6 & 5 & 2 & 6 & 3 & 6 & - & \\
\hline G. ibericus & $F: B$ & 1 & 10 & 11 & 10 & 10 & 7 & $n$ & 8 & 9 & 5 & . \\
\hline
\end{tabular}

size to 25 (Slatkin, 1985). In addition, gene flow profiles were obtained by plotting the values of the conditional average frequencies (CAF) according to Slatkin (1981). These procedures have been applied to the complete data set and to different subsets of populations. For a more detailed discussion of these methods and their application within the G. pulex-group is referred to Scheepmaker (1990).

\section{Cross-breeding experiments}

Cross-breeding experiments were conducted according to Pinkster (1983) and were carried out (a) between geographically close population samples of G. gauthieri from Morocco (station 6, area D) and southern Spain (station 10, area E); (b) between population samples of $G$. gauthieri from Morocco (station 6) and central Spain (station b, area F) and (c) between population samples of $G$. gauthieri from Morocco (station 6) and G. ibericus (station g, area F).

\section{Results}

Twenty presumptive gene loci from 17 enzyme systems were scorable in all populations. Electromorph frequencies and relative mobilities are listed in Table II. The Ada, Est-1 and Lap loci were monomorphic and fixed for the same electromorph in all population samples. The number of loci and subunit structure were consistent with the interpretation of Scheepmaker et al. (1988).

\section{Genetic variation among populations}

Differences in electromorph distribution among the samples studied are shown in Table II. G. gauthieri population samples from areas $\mathrm{D}, \mathrm{E}$ and station 5 are characterized by the $A p k^{a}, E s t-2^{b}, 6 P g d^{b}, P k^{a}$ and, except for station 5, by the Got $-2^{b}$ and Pep- $4^{b}$ electromorphs.

The $A l p-1^{a}, A l p-2^{a}, M p i^{g}$ and Pep-2 ${ }^{c}$ electromorphs are restricted to $G$. gauthieri samples from 
Table IV. Matrix of Nei's (1972) genetic distance coefficients among samples of the populations studied, averaged by area. Data from Scheepmaker et al. (1988) are included. Range $D_{\min }-D_{\max }$ in italics; $\left(^{*}\right)=$ only one population sample included.

\begin{tabular}{|c|c|c|c|c|c|c|c|c|c|c|c|c|}
\hline species & $\begin{array}{c}\text { tres / } \\
\text { etation(s) }\end{array}$ & $\begin{array}{c}\text { no. of } \\
\text { semples }\end{array}$ & 1.2 & $C ; 3,4$ & 5 & $D ; 6$ & D: $7,8,9$ & E: 10,11 & $F ; a, b$ & G;c,d,e & $F ; f$ & $F ; 8$ \\
\hline G. d. duebeni & 1.2 & 2 & $\begin{array}{c}0.00 \\
(0.00-0.00)\end{array}$ & & & & & & & & & \\
\hline G.d. celticus & C; 3,4 & 2 & $\begin{array}{c}0.25 \\
(0.21-0.29)\end{array}$ & $\begin{array}{c}0.02 \\
(0.02-0.02)\end{array}$ & & & & & & & & \\
\hline G. gauthieri & 5 & 1 & $\begin{array}{c}0.98 \\
(0.98-0.99)\end{array}$ & $\begin{array}{c}1.16 \\
(1.13-1.18)\end{array}$ & $\left({ }^{\circ}\right)$ & & & & & & & \\
\hline G. gauthieri & $\mathrm{D} ; 6$ & 1 & $\begin{array}{c}1.32 \\
(1.32-1.32)\end{array}$ & $\begin{array}{c}1.34 \\
(1.32-1.363)\end{array}$ & $\begin{array}{c}0.30 \\
(0.30-0.30)\end{array}$ & $(*)$ & & & & & & \\
\hline G.gaushieri & D; $7,8,9$ & 3 & $\begin{array}{c}1.09 \\
(1.00-1.18)\end{array}$ & $\begin{array}{c}1.20 \\
(1.10-1.36)\end{array}$ & $\begin{array}{c}0.41 \\
(0.33-0.56)\end{array}$ & $\begin{array}{c}0.32 \\
(0.25-0.42)\end{array}$ & $\begin{array}{c}0.20 \\
(0.10-0.30)\end{array}$ & & & & & \\
\hline G. gauthieri & E; 10,11 & 2 & $\begin{array}{c}1.34 \\
(1.33-1.35)\end{array}$ & $\begin{array}{c}1.55 \\
(1.52-1.58)\end{array}$ & $\begin{array}{l}0.65 \\
(0.64-0.65)\end{array}$ & $\begin{array}{c}0.54 \\
(0.53-0.54)\end{array}$ & $\begin{array}{c}0.49 \\
(0.33-0.68)\end{array}$ & $\begin{array}{c}0.01 \\
(0.01-0.01)\end{array}$ & & & & \\
\hline G. gaushieri & $\mathbf{F} ; \mathbf{a}, \mathbf{b}$ & 2 & $\begin{array}{c}1.62 \\
(1.53-1.70)\end{array}$ & $\begin{array}{c}1.96 \\
(1.84-2.04)\end{array}$ & $\begin{array}{c}0.61 \\
(0.55-0.68)\end{array}$ & $\begin{array}{c}0.47 \\
(0.41-0.52)\end{array}$ & $\begin{array}{c}0.47 \\
(0.33-0.59)\end{array}$ & $\begin{array}{c}0.31 \\
(0.30-0.33)\end{array}$ & $\begin{array}{c}0.10 \\
(0.10-0.10)\end{array}$ & & & \\
\hline G. gauthieri & G; c, d,e & 3 & $\begin{array}{c}\mathbf{0 . 9 5} \\
(0.92-0.98)\end{array}$ & $\begin{array}{c}1.08 \\
(1.02-1.14)\end{array}$ & $\begin{array}{c}0.79 \\
(0.71-0.85)\end{array}$ & $\begin{array}{c}0.62 \\
(0.56-0.66)\end{array}$ & $\begin{array}{c}\mathbf{0 . 4 7} \\
(0.39-0.51)\end{array}$ & $\begin{array}{c}0.74 \\
(0.67-0.79)\end{array}$ & $\begin{array}{c}0.70 \\
(0.60-0.78)\end{array}$ & $\begin{array}{c}0.04 \\
(0.02-0.05)\end{array}$ & & \\
\hline G. ibericus & $F ; f$ & 1 & $\begin{array}{c}1.10 \\
(1.01-1.11)\end{array}$ & $\begin{array}{c}1.32 \\
(1.26-1.39)\end{array}$ & $\begin{array}{c}0.48 \\
(0.48-0.48)\end{array}$ & $\begin{array}{c}0.48 \\
(0.48-0.48)\end{array}$ & $\begin{array}{c}0.38 \\
(0.29-0.43)\end{array}$ & $\begin{array}{c}0.47 \\
(0.47-0.47)\end{array}$ & $\begin{array}{c}0.23 \\
(0.22-0.24)\end{array}$ & $\begin{array}{c}0.55 \\
(0.50-0.57)\end{array}$ & $(*)$ & \\
\hline G. ibericus & $F ; 8$ & 1 & $\begin{array}{c}1.22 \\
(1.21-1.23)\end{array}$ & $\begin{array}{c}1.48 \\
(1.41-1.56)\end{array}$ & $\begin{array}{c}0.79 \\
(0.79-0.79)\end{array}$ & $\begin{array}{c}0.82 \\
(0.82-0.82)\end{array}$ & $\begin{array}{c}0.74 \\
(0.71-0.79)\end{array}$ & $\begin{array}{c}0.93 \\
(0.91-0.94)\end{array}$ & $\begin{array}{c}0.66 \\
(0.65 \cdot 0.66)\end{array}$ & $\begin{array}{c}1.06 \\
(0.98-1.09)\end{array}$ & $\begin{array}{c}0.39 \\
(0.39 \cdot 0.39)\end{array}$ & $(*)$ \\
\hline
\end{tabular}

area E; the Pep- $2^{d}$ electromorph characterizes $G$. gauthieri samples from stations 7,8 and 9 in area $\mathrm{D}$.

Electromorphs of other polymorphic loci are irregularly distributed within and among areas. Within area $\mathrm{D}$, at the Me locus, $G$. gauthieri samples of stations $6,7+8$, and 9 are fixed for three different electromorphs: $M e^{b}, M e^{a}$ and $M e^{e}$, respectively; $M e^{a}$ occurs also in $G$. gauthieri samples from area $\mathrm{E}$, stations $10-11 ; M e^{b}$ is also found in the $G$. gauthieri sample from station 5 . Likewise, in area D, G. gauthieri samples from stations 6 and 9 are characterized by the $M d h-I^{i}$ and $M d h-l^{e, h}$ electromorphs, that do not occur in other samples; at the Gdh locus, G. gauthieri samples from stations 8 and 9 are, unlike station 7 , fixed for the $G d h^{b}$ electromorph (also occurring in G. duebeni). The electromorph distribution at other polymorphic loci shows similar discontinuities (Table II).

$G$. d. duebeni and G. d. celticus are characterized by the predominating $A p k^{c}, E s t-2^{a}, G o t-2^{c}, H k^{c}$, $M e^{c, d}, M p i^{f}, P e p-4^{c, g}, 6 P g d^{c}$ and $P k^{c, e}$ electromorphs. Substantial differences in electromorph distribution between $G$. d. duebeni and $G$. $d$. celticus sccur at the Got-1, Mdh-1, Me, Pep-4 and Pk loci.

A half matrix of diagnostic loci ( 0.99 criterion; Ayala \& Powell, 1972) of area by area comparisons of samples of G. gauthieri, G. ibericus and G. duebeni is summarized in Table III. Values of $D$, averaged by species and by area, are shown in Table IV. Strongly "deviating" samples did not participate in this averaging.

The UPGMA dendrogram (Fig. 2) and the Jelly network (Fig. 3) show that levels of intra-specific intra-continental genetic differentiation among samples of $G$. gauthieri from within the Iberian peninsula (in particular $G$. gauthieri samples from area $G$ with regard to samples from areas $E-F$ ) may be higher than among inter-continental comparisons of samples from North Africa and the Iberian peninsula. $D$-values and the number of diagnostic loci of inter-continental comparisons among $G$. gauthieri samples from areas $\mathrm{D}$ (stations 6-9) and G (stations c, d, e) are consistently lower than those among $G$. gauthieri samples from areas 

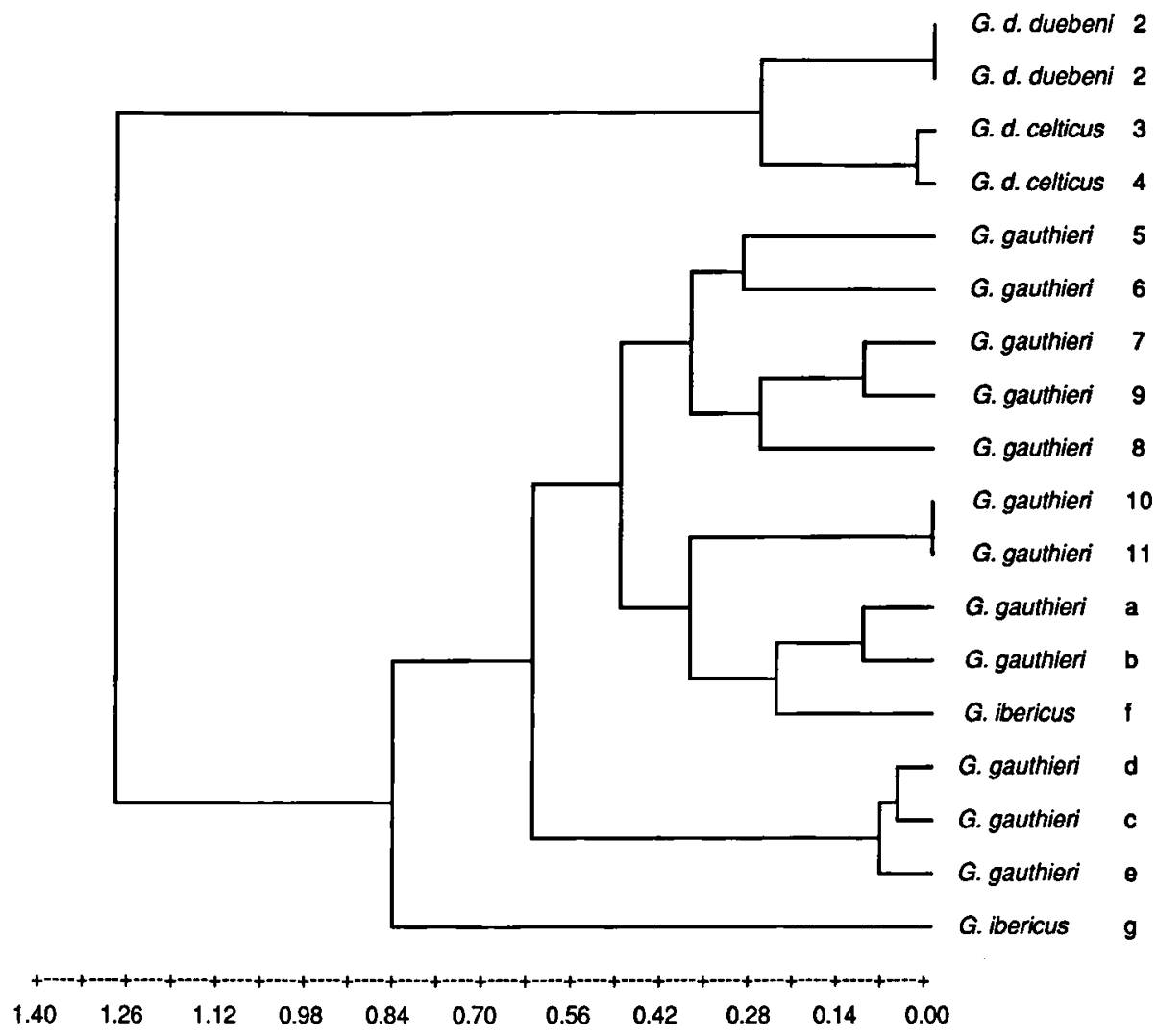

Fig. 2. UPGMA dendrogram of Nei's (1972) genetic distance $(D)$ based upon 20 enzyme loci.

D

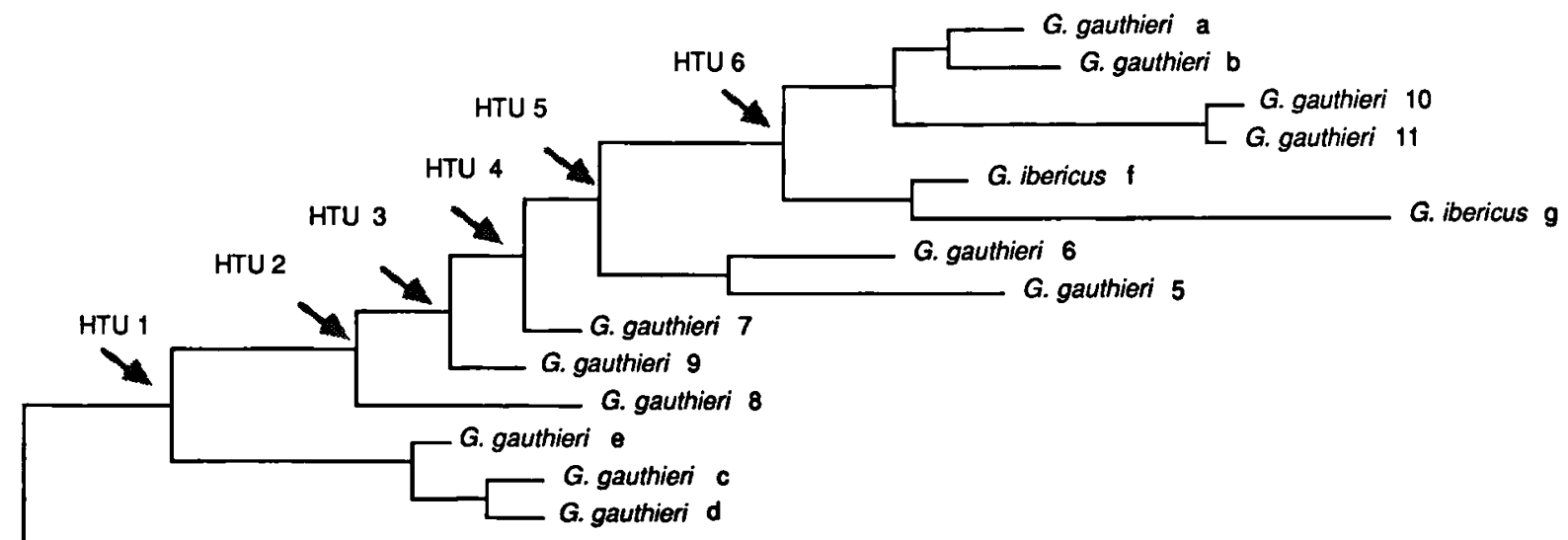

G. d. celticus 4

G. d. celticus 3

G. d. duebeni 1

G. d. duebeni 2

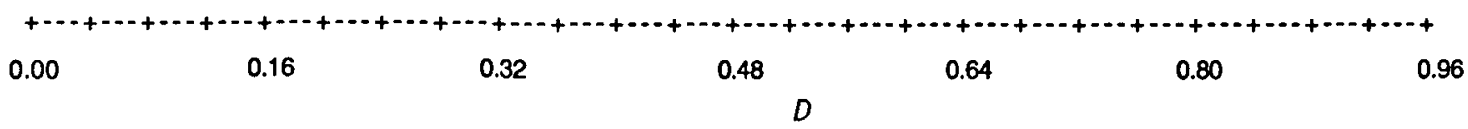

Fig. 3. Dendrogram of Jelly “character state" network (Ellis, 1987) of 20 enzyme loci, based upon Rogers' (1984) HAP algorithm, and rooted by the outgroup method (Farris, 1972). 


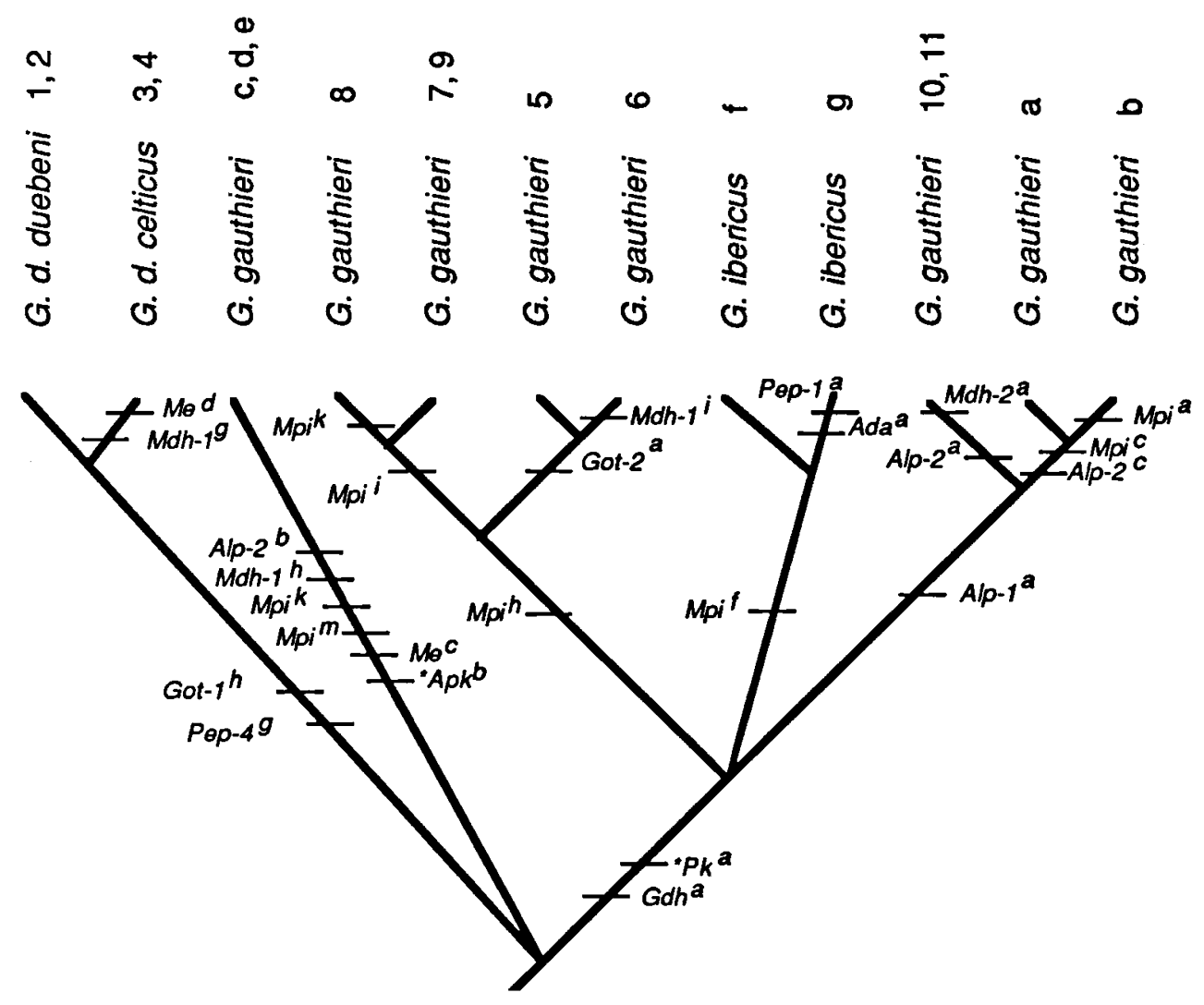

Fig. 4. The Jelly network of Fig. 3, represented as a "Hennigian tree", with internodia defined by synapomorphous electromorphs. * = not strictly contributing to clade definition (plesiomorph undetermined; Patton \& Avise, 1983).

E (stations $10-11)$ vs. $G$, and F (stations $a, b)$ vs. G, respectively (Tables III and IV). However, intercontinental $D$-values among samples from areas D and $E$, and $D$ and $F$ (Table IV) are higher than intra-continental values among areas $E$ and $F$. These values are also higher than intra-areal $D$ values of area $D$, and $D$-values among station 5 and stations 6-9 (Table IV). Inter-continental $D$-values among $G$. gauthieri samples from the geographically closest areas D and E, and the much more distant areas D and F, do not differ substantially (Table IV). It is also interesting to note that $D$-values of inter-specific inter-continental comparisons among G. gauthieri from area D (stations 7-9) and $G$. ibericus from station $f$ are lower than those among G. gauthieri from area E (stations 10-11) and $G$. ibericus from station $f$ (Table IV).

According to the UPGMA dendrogram (Fig. 2), G. gauthieri from North Africa (stations 5-9) forms a monophyletic group with the central Iberian G. gauthieri from stations 10-11 (area E), a-b (area F) and $G$. ibericus from station $\mathrm{f}$ (area F), thus apart from the western Iberian $G$. gauthieri from stations c-e (area $G$ ) and $G$. ibericus from station $\mathrm{g}$ (area F). Within this cluster, North African population samples (stations 5-9) form a clearly distinct subcluster, whereas southern Iberian G. gauthieri (stations 10-11) clusters with central Iberian $G$. gauthieri $+G$. ibericus from station $\mathrm{f}$. This is in contrast with the Jelly network (Fig. 3), where $G$. gauthieri samples from the North African stations $7-9$, and 5,6 are represented by successive branches between the clusters formed by $G$. gauthieri from area G (western Spain; Fig. 1A), and G. gauthieri $+G$. ibericus from southern and central Spain. Moreover, $G$. ibericus from stations $f$ and $\mathrm{g}$ cluster together.

When the branches of the Jelly network are 
Table $\mathrm{V}$. Intercontinental values of the mean genetic distance (D) and standard error (s.e.) among stations and areas in North Africa and the Iberian peninsula, jack-knifed over 20 enzyme loci. Corresponding values of one unit $D$ are listed along; these values are based on a separation of $5.5 \mathrm{My}$; for station legend see Table I.

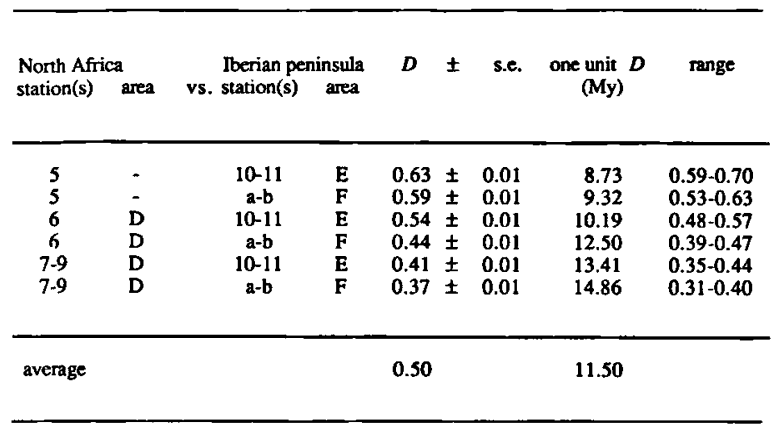

defined by synapomorphic electromorphs (Fig. 4), internodia defining $G$. gauthieri from stations $\mathrm{c}-\mathrm{e}$, and $G$. ibericus from stations $\mathrm{f}-\mathrm{g}$ are represented by trichotomies. Furthermore, the successive branches of the North African stations 7-9, and 5, 6 form a monophyletic group. The topology of this "Hennigian tree" is in outline (except for the trichotomies) similar to the UPGMA dendrogram.

To provide a calibration of the molecular clock, inter-continental intra-specific $D$-values among $G$. gauthieri from stations 5, 6, 7-9 (area D), stations 10, 11 (area E) and a, b (area F) were jack-knifed over loci (Table V). According to Hsü et al. (1977), the opening of the Strait of Gibraltar occurred 6-5 My ago. Thus, based on $5.5 \mathrm{My}$, a $D_{\text {mean }}$-value of 0.50 for inter-continental comparisons corresponds to a one unit $D$-value of $11.5 \mathrm{My}$.

\section{Genetic structure of populations and estimated levels of gene flow}

The results of the $F$-statistic analysis $(\theta)$ for $G$. gauthieri, G. ibericus, G. d. duebeni and G.d. celticus are shown in Table VI. Statistically significant population subdivision was found for G. gauthieri, G. ibericus and G. d. celticus at most polymorphic loci: all 16 in G. gauthieri; all 8 in the two samples of $G$. ibericus, and all 4 in $G$. $d$. celticus. This degree of subdivision is about the same as recorded in combined datasets with $G$. gauthieri and $G$.
Table VI. $\theta$-indices according to Weir \& Cockerham (1984) of the samples examined. G. gauth. = G. gauthieri; G. ib. =G. ibericus; G. d. dueb. = G. d. duebeni; G.d. celt. = G. d. celticus. Significance of population subdivision was tested with a chi-square heterogeneity test. ${ }^{*}=P<0.05$. Data of Scheepmaker et al. (1988) are included.

\begin{tabular}{|c|c|c|c|c|c|c|}
\hline $\begin{array}{l}\text { species } \\
\text { Area(s) } \\
\text { Stations }\end{array}$ & $\begin{array}{c}\text { G. gauth. } \\
\text { G. ib. } \\
\text { D-G } \\
5-11 \text {, a-g }\end{array}$ & $\begin{array}{c}\text { G. gauth. } \\
\text { D-G } \\
\text { 5-11, a-e }\end{array}$ & $\begin{array}{c}\text { G. } i b . \\
\underset{f, g}{F}\end{array}$ & $\begin{array}{c}\text { G.d.dueb. } \\
\text { G.d. celt. } \\
-, \mathrm{C} \\
\text { 1-4 }\end{array}$ & $\begin{array}{c}\text { G.d.dueb. } \\
- \\
1,2\end{array}$ & $\begin{array}{c}\text { G.d. celt. } \\
\text { C } \\
3,4\end{array}$ \\
\hline \multicolumn{7}{|l|}{ locus } \\
\hline Ada & $1.00^{*}$ & - & $1.00^{*}$ & - & - & - \\
\hline$A p k$ & $0.49^{*}$ & $0.48 *$ & - & - & - & - \\
\hline Alp.1 & $1.00^{*}$ & $1.00^{*}$ & - & - & - & - \\
\hline Alp -2 & $0.89^{*}$ & $0.87^{*}$ & - & - & - & - \\
\hline Est-1 & $1.00^{*}$ & $1.00^{*}$ & - & - & - & - \\
\hline Est-2 & 0.04 & $0.88^{*}$ & $1.00^{*}$ & - & - & - \\
\hline$G d h$ & $1.00^{*}$ & $1.00^{*}$ & - & - & - & - \\
\hline Got-1 & $0.99^{*}$ & $0.86^{*}$ & $1.00^{*}$ & $0.65^{*}$ & 0.05 & $0.40^{*}$ \\
\hline Got-2 & $0.78^{*}$ & $0.98^{*}$ & $0.46^{*}$ & 0.00 & 0.00 & - \\
\hline$G p i$ & $0.65^{*}$ & $0.66^{*}$ & $0.59^{*}$ & $0.59^{*}$ & 0.05 & $0.21 *$ \\
\hline$H k$ & $1.00^{*}$ & - & $1.00^{*}$ & - & - & - \\
\hline$M d h-I$ & $0.91^{*}$ & $0.90^{*}$ & - & $0.87^{*}$ & 0.02 & $0.10^{*}$ \\
\hline Mdh-2 & $0.91^{*}$ & $0.91^{*}$ & - & - & - & - \\
\hline$M e$ & $1.00^{*}$ & $1.00^{*}$ & - & $0.99 *$ & 0.00 & - \\
\hline$M p i$ & $0.81^{*}$ & $0.82^{*}$ & $0.71^{*}$ & - & - & - \\
\hline$P_{c p-2}$ & $0.91^{*}$ & $0.88^{*}$ & $0.99^{*}$ & - & - & - \\
\hline Pep-4 & $0.86^{*}$ & $0.80^{*}$ & - & $0.32^{*}$ & $0.04^{*}$ & $0.36^{*}$ \\
\hline$P k$ & $0.94^{*}$ & $0.94^{*}$ & - & $1.00^{*}$ & - & - \\
\hline Mean & 0.89 & 0.89 & 0.89 & 0.74 & 0.04 & 0.29 \\
\hline
\end{tabular}

ibericus (Tables VI, VII). However, much less population subdivision was found in the brackish/marine form $G$. d. duebeni. Creating subsets of samples of $G$. gauthieri by omitting the most "deviating" samples, by combining samples by area, or by pairwise combinations of geographically close samples does not change this pattern. These subsets show that statistically significant population subdivision still exists over small geographic ranges (Table VII).

Mean values of $\theta$ within species and subsets of population samples are listed in Tables VIII and IX, along with the derived $N m$-values $\left(N m_{\theta}\right)$. The average frequencies of private alleles $\bar{p}(1)$ and the derived $\mathrm{Nm}$ - and $\mathrm{Nm}^{*}$-values (Slatkin, 1985) were calculated for sets of four samples and more.

Genetic drift and bottlenecks will result in substantial local differentiation if $\mathrm{Nm}<1$; when $\mathrm{Nm}$ $>1$, populations tend to become panmictic for neutral alleles (e.g. Wright, 1931). Except for G. $d$. duebeni (stations 1 and 2) and G. gauthieri from 


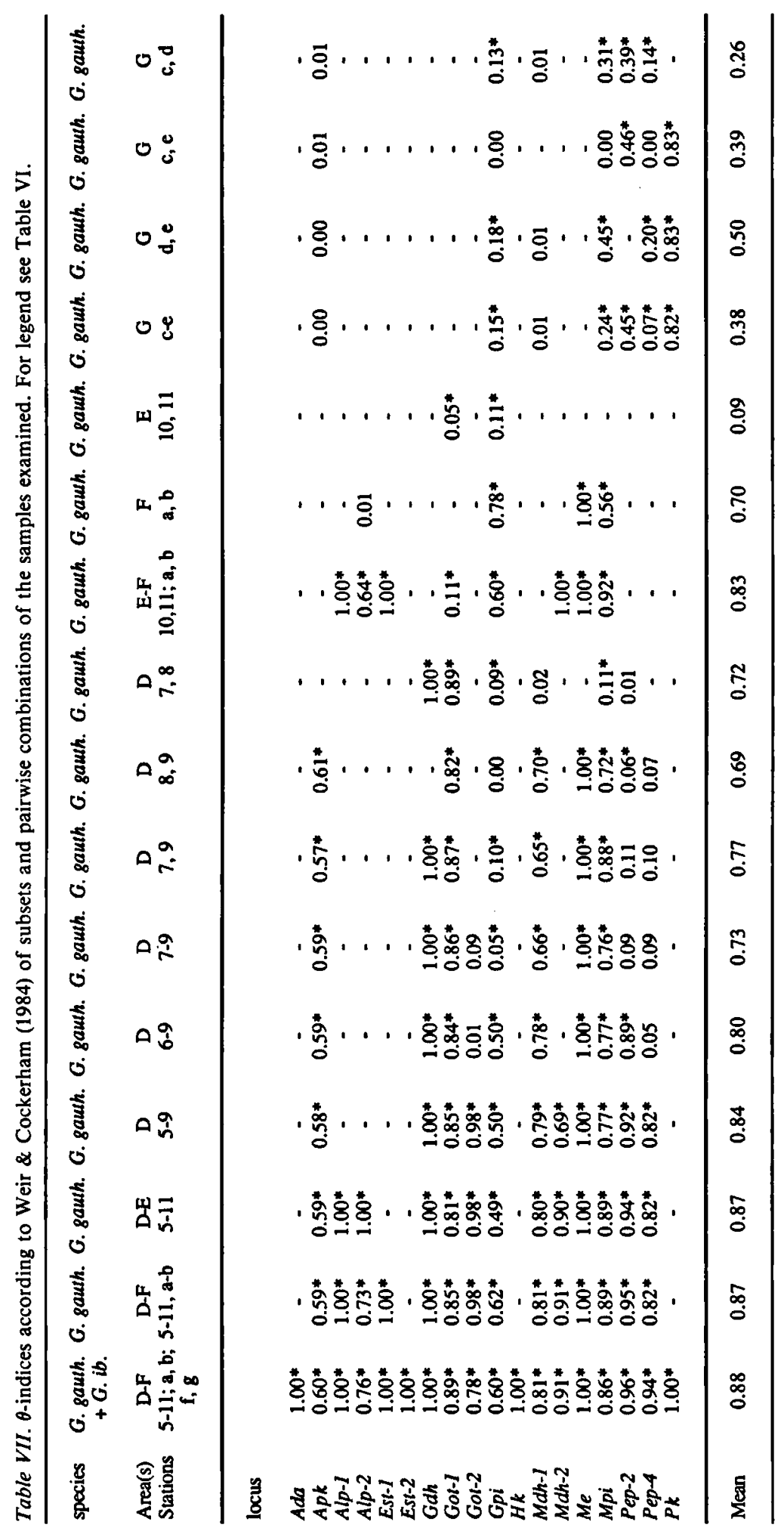


Table VIII. Various $N m$ estimates in G. gauthieri, G. ibericus, G. d. duebeni and $G$. $d$. celticus. n.p.a. = number of private alleles; $\bar{p}(1)=$ average frequency of private alleles (Slatkin, 1985); $N m=$ estimate derived from $\bar{p}(1) ; \mathrm{Nm}^{*}=$ idem, with correction for sample size; $\theta=F$-statistic (Weir \& Cockerham, 1984); $N m_{\theta}=$ estimate derived from $\theta ; \mathbf{k m}(\mathrm{av})=$ average geographic distance among samples in kilometres. Data of Scheepmaker et al. (1988) are included.

\begin{tabular}{|c|c|c|c|c|c|c|c|c|c|c|c|}
\hline Species & Area(s) & Stations & $\begin{array}{l}\text { No. of } \\
\text { samples }\end{array}$ & $\boldsymbol{\theta}$ & n.p.a. & $\bar{p}(1)$ & Nav & $N m$ & $N m^{*}$ & $N m_{\theta}$ & km(av) \\
\hline $\begin{aligned} & \text { G. gauthieri } \\
+ & \text { G. ibericus }\end{aligned}$ & D,E,F,G & $5-11 ; a-g$ & 14 & 0.89 & 15 & 0.58 & 41.08 & 0.02 & 0.01 & 0.03 & 403 \\
\hline G. gauthieri & $\mathrm{D}, \mathrm{E}, \mathrm{F}, \mathrm{G}$ & $5-11 ; a-e$ & 12 & 0.88 & 13 & 0.47 & 39.20 & 0.04 & 0.02 & 0.04 & 423 \\
\hline $\begin{aligned} & \text { G. gauthieri } \\
+ & \text { G. ibericus }\end{aligned}$ & $\mathrm{D}, \mathrm{E}, \mathrm{F}$ & 5-11; a-b, f-g & 11 & 0.89 & 19 & 0.50 & 38.30 & 0.03 & 0.02 & 0.03 & 380 \\
\hline G. gauthieri & $\mathrm{D}, \mathrm{E}, \mathrm{F}$ & $5-11 ; a-b$ & 9 & 0.87 & 15 & 0.42 & 37.58 & 0.04 & 0.03 & 0.04 & 405 \\
\hline G. gauthieri & $\mathrm{D}, \mathrm{E}$ & $5-11$ & 7 & 0.87 & 14 & 0.43 & 35.71 & 0.04 & 0.03 & 0.04 & 256 \\
\hline G. gauthieri & D & $5-9$ & 5 & 0.84 & 15 & 0.42 & 35.80 & 0.04 & 0.03 & 0.05 & 235 \\
\hline G. gauthieri & D & $6-9$ & 4 & 0.80 & 15 & 0.58 & 35.82 & 0.02 & 0.02 & 0.06 & 34 \\
\hline G. gauthieri & D & $7-9$ & 3 & 0.73 & - & - & - & - & - & 0.09 & 41 \\
\hline G. gauthieri & E, F & $10-11 ; a-b$ & 4 & 0.83 & 7 & 0.55 & 39.80 & 0.03 & 0.02 & 0.05 & 400 \\
\hline G. gauthieri & $\mathbf{G}$ & $c-e$ & 3 & 0.38 & - & - & - & - & - & 0.41 & 40 \\
\hline $\begin{array}{r}\text { G. d. duebeni } \\
+ \text { G.d. celticus }\end{array}$ &,$- C$ & $1-4$ & 4 & 0.74 & 4 & 0.05 & 36.03 & 3.13 & 2.17 & 0.09 & 341 \\
\hline
\end{tabular}

area $\mathrm{E}$ (stations 10 and 11 ), in all species and subsets examined, $\mathrm{Nm}$-values derived from $\theta\left(N m_{\theta}\right)$ are less than one (Tables VII, IX), suggesting an important degree of genetic isolation. Except for the $G$. gauthieri samples from stations 10 and 11 , there is no correlation between $\mathrm{Nm}_{\theta}$-values and geographic distance (Tables VIII and IX). These data suggest that substantial barriers to gene flow occur over small geographic ranges.

$\mathrm{Nm}$-estimates according to Slatkin, 1985 (in particular estimates uncorrected for sample size) show a very close agreement with $N m_{\theta}$-estimates (Table VIII); however, the two estimates contrast in the dataset formed by $G$. $d$. duebeni and $G$. d. celticus (stations 1-4).

The results of the CAF analysis (Slatkin, 1981) of gene flow levels in different sets and subsets of $G$. gauthieri populations (whether or not in combination with the related form $G$. ibericus) are represented in Figs. 5 and 6. All gene flow profiles show high initial $\bar{p}(i)$-values, and almost all exhibit wide fluctuations. These curves resemble closely those presented by Slatkin (1981) as characteristic for low-gene-flow species (see Scheepmaker, 1990).
Table IX. Various $\mathrm{Nm}$ estimates in pairwise combinations of samples of G. gauthieri, G. ibericus, G. d. duebeni and G.d. celticus. For legend see Table VIII.

\begin{tabular}{llcccc} 
Species & Area & Stations & $\theta$ & $N m_{\theta}$ & $\mathrm{km}(\mathrm{av})$ \\
\hline G. gauthieri & G & c, e & 0.39 & 0.39 & 48 \\
G. gauthieri & G & d, e & 0.50 & 0.25 & 54 \\
G. gauthieri & G & c, d & 0.26 & 0.72 & 17 \\
G. gauthieri & E & 10,11 & 0.09 & 2.38 & 8 \\
G. gauthieri & D & 7,9 & 0.77 & 0.08 & 44 \\
G. gauthieri & D & 8,9 & 0.69 & 0.11 & 19 \\
G. gauthieri & D & 7,8 & 0.72 & 0.10 & 64 \\
G. gauthieri & F & a, b & 0.70 & 0.11 & 35 \\
G. ibericus & F & f, g & 0.89 & 0.03 & 26 \\
G.d.duebeni & - & 1,2 & 0.04 & 5.98 & 400 \\
G.d.celticus & C & 3,4 & 0.29 & 0.61 & 24
\end{tabular}

\section{Cross-breeding experiments}

The results of the cross-breeding experiments are listed in Table X. Due to high mortality rates (probably caused by unknown compounds in the Amsterdam tap water) in population samples from southern Spain (area E) and Morocco (area D), experimental conditions were not always optimal. All 
Table $X$. Results of cross-breeding experiments between samples of $G$. gauthieri and $G$. ibericus from North Africa and the Iberian peninsula. $g_{6}=G$. gauthieri from station $6 ; g_{10}=G$. gauthieri from station $10 ; g_{b}=G$. gauthieri from station b; $i_{g}=G$. ibericus from station $\mathrm{g}$; for legend stations see Table $\mathbf{I}$.

\begin{tabular}{|c|c|c|c|c|c|c|}
\hline ९ & $\begin{array}{l}\text { ross } \\
\times \sigma^{\circ} 0^{\circ}\end{array}$ & $N$ of $\$$ Q & $\mathrm{N}$ of $0^{\circ} 0^{\circ}$ & $\begin{array}{l}\mathrm{N} \text { of } \\
\text { ovigerous } ९ \text { Q }\end{array}$ & $\begin{array}{l}\mathrm{N} \text { of ovigerous } \\
९ ९ \text { with offspring }\end{array}$ & $\begin{array}{l}\mathrm{F} 2 \\
\text { obtained }\end{array}$ \\
\hline$g_{6}$ & $\times g_{6}$ & 122 & 84 & 53 & 32 & + \\
\hline$g_{10}$ & $\times g_{10}$ & 7 & 6 & 3 & 1 & - \\
\hline$g_{b}$ & $\times g_{b}$ & 17 & 17 & 14 & 8 & + \\
\hline$i_{g}$ & $\times i_{g}$ & 50 & 50 & 30 & 10 & + \\
\hline$g_{6}$ & $\times \mathrm{g}_{10}$ & 60 & 16 & - & - & - \\
\hline$g_{10}$ & $\times g_{6}$ & 23 & 26 & 8 & 1 & - \\
\hline$g_{6}$ & $\times i_{g}$ & 36 & 36 & 13 & 9 & + \\
\hline$i_{g}$ & $\begin{array}{r}8 \\
\times g_{6}\end{array}$ & 84 & 52 & 4 & - & - \\
\hline$g_{6}$ & $\times g_{b}$ & 50 & 31 & 18 & 4 & - \\
\hline$g_{b}$ & $\times g_{6}$ & 107 & 90 & 6 & - & - \\
\hline
\end{tabular}

Table XI. Distribution of numbers of electromorphs common in western European, Iberian and North African members of the G. pulexgroup in samples from North Africa and the Iberian peninsula; for legend stations see Table $I$.

\begin{tabular}{|c|c|c|c|c|c|c|c|c|}
\hline $\begin{array}{l}\text { species } \\
\text { area } \\
\quad \text { station(s) }\end{array}$ & $\begin{array}{c}\text { G. gauthieri } \\
- \\
5 \\
\text { Morocco }\end{array}$ & $\begin{array}{l}\text { G. gauthieri } \\
\text { D } \\
6 \\
\text { Morocco }\end{array}$ & $\begin{array}{c}\text { G. gauthieri } \\
\text { D } \\
7-9 \\
\text { Morocco }\end{array}$ & $\begin{array}{c}\text { G. gauthieri } \\
\text { E } \\
10-11 \\
\text { Spain }\end{array}$ & $\begin{array}{l}\text { G. gauthieri } \\
\text { F } \\
\text { a, b } \\
\text { Spain }\end{array}$ & $\begin{array}{l}\text { G. ibericus } \\
\mathbf{F} \\
\mathbf{f} \\
\text { Spain }\end{array}$ & $\begin{array}{l}\text { G. ibericus } \\
\text { F } \\
\text { g } \\
\text { Spain }\end{array}$ & $\begin{array}{c}\text { G. gauthieri } \\
\text { G } \\
\text { C-e } \\
\text { Spain }\end{array}$ \\
\hline $\begin{array}{l}\text { Common in western European } \\
\text { members of the } G \text {. pulex-group }\end{array}$ & 15 & 18 & 27 & 15 & 16 & 20 & 17 & 17 \\
\hline Common in $G$. duebeni & 8 & 6 & 11 & 7 & 8 & 8 & 11 & 10 \\
\hline $\begin{array}{l}\text { Common in western European members } \\
\text { of the } G \text {.pulex-group; } \\
\text { present in Iberian samples; } \\
\text { lacking in North African samples }\end{array}$ & - & - & - & 2 & 1 & 4 & 6 & 4 \\
\hline $\begin{array}{l}\text { Common in western European members } \\
\text { of the } G \text {. pulex-group; } \\
\text { present in North African samples; } \\
\text { lacking in Iberian samples }\end{array}$ & 2 & 2 & 5 & - & - & - & - & - \\
\hline $\begin{array}{l}\text { Restricted to both North African and } \\
\text { Iberian samples }\end{array}$ & 5 & 5 & 8 & 4 & 3 & 3 & 3 & 6 \\
\hline Exclusively in North African samples & 0 & 1 & 0 & - & - & - & - & - \\
\hline Exclusively in Iberian samples & - & - & - & 2 & 2 & 0 & 3 & 2 \\
\hline
\end{tabular}

reference crosses but one $\left(g_{10} \times g_{10}\right)$ yielded $\mathrm{F} 2$ offspring. In three combinations, F2 could not be obtained in reciprocal crosses: $g_{6} \times g_{10}, i_{g} \times g_{6}$, and $g_{b} \times g_{6}$. In one cross, $g_{6} \times i_{g}$, F2 could be obtained ( $g$ refers to $G$. gauthieri; $i$ to $G$. ibericus; 6 , $10, \mathrm{~b}$, and $\mathrm{g}$ to stations $6,10, \mathrm{~b}$, and $\mathrm{g}$, respectively).

\section{Discussion and conclusions}

Electromorph distribution with reference to central Iberian G. gauthieri samples and related taxa of western Europe north of the Pyrenees

Differences in electromorph distribution among 

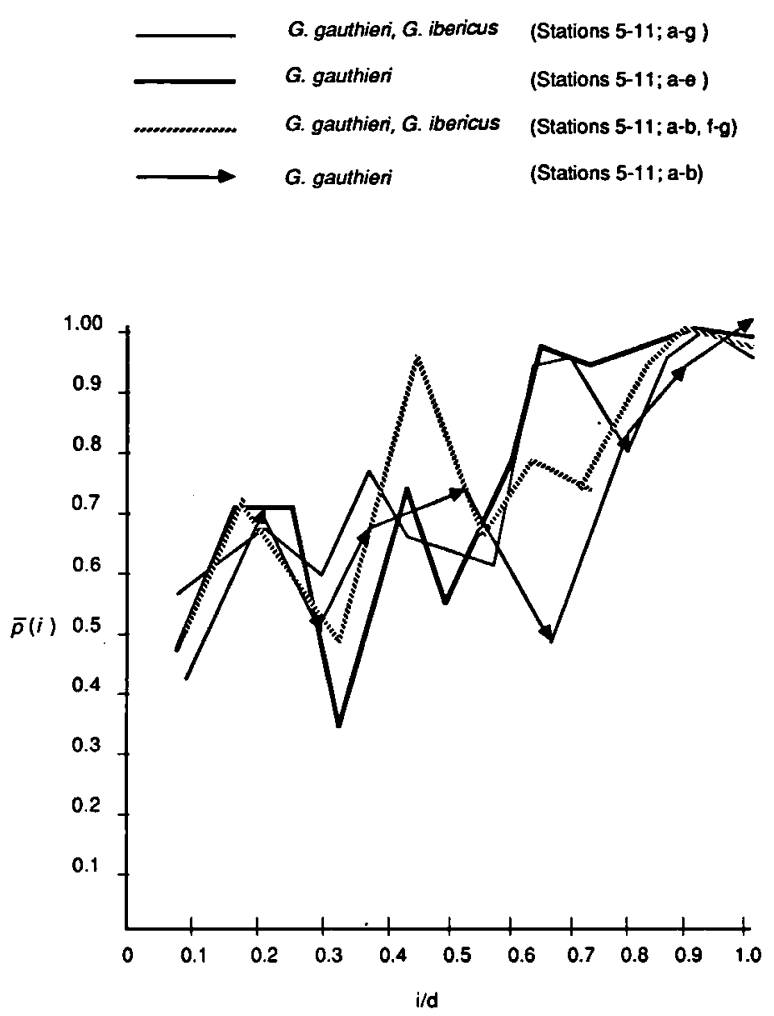

Fig. 5. CAF gene flow profiles (Slatkin, 1981) in G. gauthieri and $G$. ibericus. $\bar{p}(i)=$ conditional average frequency (CAF) of an electromorph; $i / d=$ incidence of an electromorph, where $i=$ the total number of samples it appears in, and $d=$ the total number of samples examined. The points plotted are average values of $\bar{p}(i)$ for electromorphs having the same $i / d$-value. For station legend see Table I.

southern Iberian and North African G. gauthieri samples are less conspicuous than among samples within the Iberian peninsula; however, with regard to taxa north of the Pyrenees, G. gauthieri is much more differentiated. Electromorph frequency data of G. gauthieri, G. ibericus and members of the $G$. pulex-group in northwestern Europe were reported by Scheepmaker et al. (1988), Scheepmaker \& Van Dalfsen (1989) and Scheepmaker (1990), respectively. The numbers of electromorphs in population samples of G. gauthieri and G. ibericus from North Africa and the Iberian peninsula in common with members of the $G$. pulex-group in North-West Europe are listed in Table XI. The highest number of "western European" electromorphs was found in area D (North Africa); however, samples from
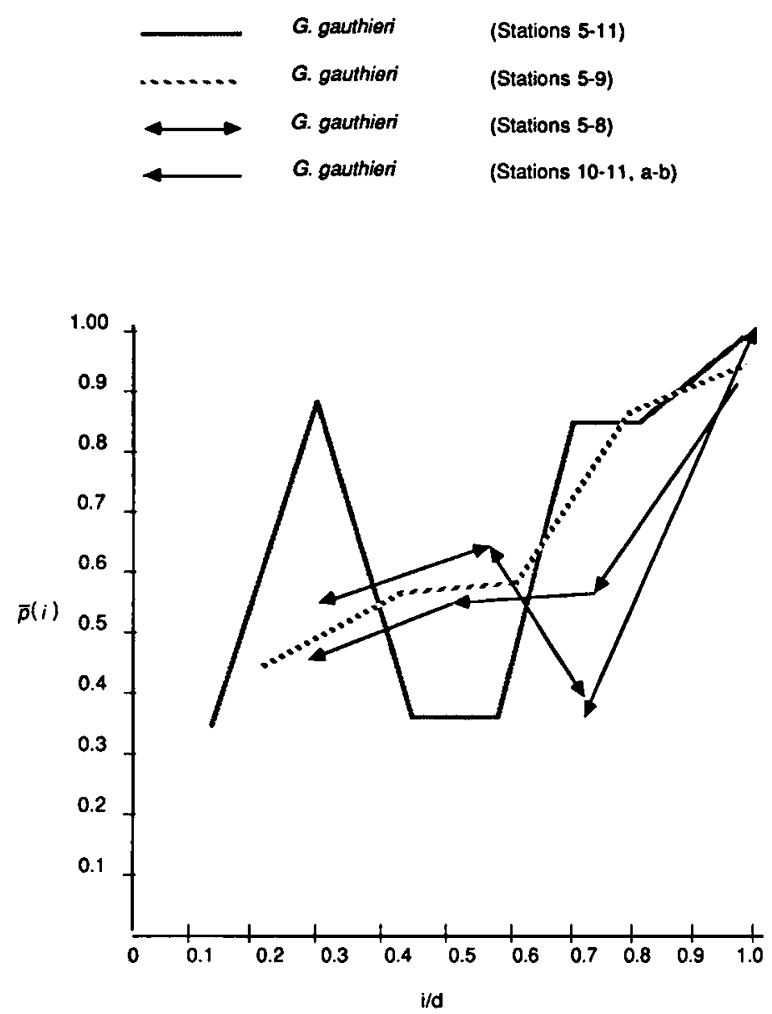

Fig. 6. CAF gene flow profiles in subsets of G. gauthieri. For legend see Fig. 5 .

this area also exhibit the highest levels of polymorphism. The combination of the fixed electromorphs Alp- $1^{b}$ and $A l p-2^{c}$ for instance, that occurs in all North African samples, is typical for all western European taxa of the $G$. pulex-group (this combination, also found in the outgroup $G$. duebeni, is to be considered plesiomorphic). The $G p i^{e}, f, g, h, i$ and the $M p i^{h, i}$ electromorphs are common in western European members of the G. pulex-group and North African G. gauthieri, but lack in most populations of $G$. gauthieri from the Iberian peninsula, etc. The simultaneous occurrence of fixed $A p k^{a}, 6 P g d^{b}$ and $P k^{a}$ electromorphs (occurring in all North African samples) is never found in members of the $G$. pulex-group in North-West Europe and characterizes G. gauthieri (and G. ibericus) from the Iberian peninsula; likewise, the Est-2 ${ }^{b}$ electromorph is fixed in all Iberian and North African samples of $G$. gauthieri and is rare among western European members of the $G$. pulex- 
group. Although North African G. gauthieri populations exhibit some (in part plesiomorphic) characters that are typical for North-West European members of the $G$. pulex-group, electromorphs characterizing taxa from the Iberian peninsula dominate.

The $A p k^{a}, E s t-2^{b}$ and $6 P g d^{b}$ electromorphs are shared by all samples of $G$. gauthieri from area $G$ (stations c-e), and G. gauthieri and G. ibericus from areas D-F (stations 5-11, $a-b$ and $f-g$ ). However, as the plesiomorph remains undetermined, they do not contribute to clade definition (although they may provide supporting evidence for previously defined clades; Patton \& Avise, 1983). Therefore, no clade can be defined including all these samples (Fig. 4).

Electromorphs occurring only in either all Iberian or all Morroccan population samples of $G$. gauthieri were not found. On the other hand, the highest number of "endemic" electromorphs were found among $G$. gauthieri plus $G$. ibericus from the Iberian peninsula. Moreover, inter-continental inter-areal $D$-values among areas $\mathrm{D}$ and $\mathrm{G}$ are lower than intra-continental inter-areal $D$-values among areas $E$ and $F$ vs. area $G$. These data suggest that not all populations accumulate evolutionary change at the same rate (i.e., faster rates occur in taxa from the Iberian areas $E$ and F).

\section{Genetic differentiation, origin and dispersal}

According to Fig. 2, western Iberian G. gauthieri from area $G$ cluster apart from North African, and southern and central Iberian G. gauthieri from station 5 and areas D, E and F. North African $G$. gauthieri samples (stations 5-9) form a clearly distinct subcluster among southern and central Iberian $G$. gauthieri and $G$. ibericus samples from areas E and F. This pattern suggests that North African populations of $G$. gauthieri originate from the Iberian peninsula, in particular from common ancestors with $G$. gauthieri from areas $\mathrm{E}$ and $\mathrm{F}$.

According to the Jelly network (Fig. 3), a western European ancestor gave rise to (ancestors of) $G$. duebeni, and next, to common ancestors of Iberian and North African G. gauthieri (HTU 1 in Fig. 3).
North African G. gauthieri populations (station 5, area D) originate in 4 successive branches from common ancestors with $G$. gauthieri (and $G$. ibericus) from areas E and F (HTU's 2-6). The 4 successive branches of stations $5-6,7,8$ and 9 suggest that the Strait of Gibraltar was traversed four times (or a commuting movement). However, if these branches (HTU's 2-6) are considered as a polytomy, or as a monophyletic group (as in the "Hennigian tree" of Fig. 4), traversing once suffices.

From HTU 1 to HTU 2, important changes in frequency distribution occur at the Gpi, Pep-2 and Pep-4 loci. However, HTU 2-6 (i.e. the 4 successive branches) are rather similar and differ essentially by gradual changes at the Gpi, Got-1,Me and Mpi loci (except for HTU 3 to HTU 4, where the plesiomorphic fixed $G d h^{b}$ electromorph is replaced by $G d h^{a}$ ). Therefore, it may be justified to represent HTU 2-6 as a polytomy. As for the remaining loci, HTU 1-6 are all characterized by the fixed $A l p-1^{b}, A l p-2^{c}, E s t-1^{b}$ (all plesiomorphic), Est-2 ${ }^{b}$, $H k^{b}$, and $6 P g d^{a}$, and predominant $A p k^{a}$ and $P k^{a}$ electromorphs (for sake of space, HTU frequency data are not reproduced here).

As pointed out by Scheepmaker et al. (1988), Iberian and North African G. gauthieri and $G$. ibericus are likely to originate from northwestern European and not from African ancestors. Gammarids are lacking in the rest of Africa, and a major adaptive shift of a species group from temperate to more extreme conditions seems improbable (Golikov \& Tzvetkova, 1972). Unless the extension of (ancestors of) G. gauthieri included the Tyrrhenian and Calabrian areas (which are at present devoid of G. gauthieri-like forms; Pinkster, pers. comm.), and unless $G$. gauthieri reached North Africa from the East after the junction of the Eurasian and African plates, the most obvious dispersal route is via the northeastern part of the Iberian peninsula (before the upheaval of the Pyrenees), and from there to southern Spain and North Africa.

\section{Geographical barriers to gene flow and vicariant events}

Today, geographic and climatological factors prevent the genetic exchange among areas $D$ and $G$. 
Area $\mathrm{G}$ is at present primarily separated from the other areas by the Hercynian Sierra de Gredos, Sierra de Guadarrama and Celtiberic Cordillera; this barrier may have been effective since preMessinian times (Ager, 1980; Scheepmaker et al., 1988). Areas F and E are separated by the more recent, Alpine Betic Cordillera, and areas D and E-F by the Strait of Gibraltar.

In addition to recent and historical barriers, preMessinian subdivision of ancestral populations may also account for the genetic divergence recorded among $G$. gauthieri and $G$. ibericus from areas $D, E$ and F. Since the Eocene-Oligocene boundary, the emerged eastern part of the Iberian peninsula (reaching from the Betic Cordillera via the Balearic promontory, Sardinia and Corsica up to southern France) was separated from the western part by marine transgressions (e.g. the formation of the Valencia trough) and fragmented repeatedly by tectonic activity and successive marine transgressions and retreats (Pomerol, 1973; Dercourt et al., 1985; Maldonado, 1985). The Betics (including area E) must have resembled an archipelago during several phases of its history (Notenboom, 1988).

Ancestors of $G$. gauthieri were possibly already present on the former Betic Archipelago (including area $\mathrm{E}$ and the Moroccan Rif area) and the formerly emerged eastern part of the Iberian peninsula, as probably were (ancestors of) Echinogammarus klaptoczi ebusitanus Schäferna, 1908 and E. sicilianus sicilianus Karaman \& Tibaldi, 1973. The latter two species are actually known from Mallorca, Menorca, Ibiza, Malta and Libya (North Africa), and from Mallorca and Sicily, respectively (Stock, 1978; Stock, pers. comm.). However, the absence of G. gauthieri or any related forms in other rudiments of this former land such as the Balearic Islands and Sardinia (Pinkster, pers. comm.) suggests that (an ancestor of) G. gauthieri has not extended to this area until the Messinian salinity crisis (6-5 My ago). Unless G. gauthieri invaded North Africa from the East after the junction of the Eurasian and African plates, this was likely to happen from the Iberian peninsula.

$D$-values among samples from areas $\mathrm{E}$ and $\mathrm{F}$ are not much higher than among North African and Iberian samples from areas $\mathrm{E}$ and $\mathrm{F} ; D$-values among North African and Iberian samples from area $G$ are even lower than among samples from areas E-F, and area G. If G. gauthieri did reach North Africa from the East, these values would have been (presumably) much higher.

In North Africa, $D$-values of samples from station 6 vs. stations 7-9 (all area D; mean distance c. $50 \mathrm{~km}$ ) are higher than those between stations 5 and 6 (High Atlas and Middle Atlas respectively; geographic distance c. 420 km; Tables IV, VIII). As these areas were separated by marine transgressions during the Pliocene, the presence of G. gauthieri in the High Atlas may be relatively recent.

Today, desertification as a result of deforestation and erosion in many areas (e.g. central Spain, parts of the Betic Cordillera, the Rif zone in North Africa, etc.) represents important barriers among some of these areas. Due to semi-arid conditions and pollution gammarids disappeared from many localities. The resulting degree of discontinuity among conspecific samples (even within the same area or drainage system) makes it difficult to find relationships among areas. However, as intra-continental $D$-values among both North African and Iberian population samples are lower than inter-continental values among North Africa and the Iberian peninsula, the opening of the Strait of Gibraltar is probably the most important among factors limiting gene flow.

\section{Calibration of the molecular clock}

An initial calibration of the molecular clock can be performed when inter-continental values of $D$ exceed intra-continental $D$-values. Samples of $G$. gauthieri from areas $\mathrm{E}$ and $\mathrm{F}$ (forming a monophyletic group in Figs. 2 and 3) satisfy this requirement. However, the data set reported here represents a serious risk of pitfalls. The range of $D$-values resulting from the jack-knife procedure is $0.31-0.70$ (Table V). Moreover, the opening of the Strait of Gibraltar may be dated at $5,5.5$ or $6 \mathrm{My}$ ago. Consequently, one unit $D$ may range from 7.1 to $19.3 \mathrm{My}$ based on the same data set. In addition, the stations sampled do not necessarily represent the geographically closest areas on either side of the 
Strait of Gibraltar; genetically closer forms may have occurred in areas being devoid of gammarids today (e.g. the Rif zone and the southernmost Betics).

Rates of accumulation of genetic change may be strongly biased by stochastic processes. Averaging over several samples from an area may not compensate for this effect. Thus, the present calibration should not be applied to species that are much less subjected to stochastic processes (e.g. G. d. duebeni, G. zaddachi and G. tigrinus; Scheepmaker, 1990). Moreover, populations on either side of the Strait of Gibraltar possibly do not accumulate evolutionary change at the same rate (e.g. areas $E$, F). Consequent to these uncertainties, other data sets and well-dated geological events are required to provide conclusive evidence for the meaning of the present calibration. With reference to literature data, a one unit $D$-value of 11.5 fits in the range of values (5-20 My) proposed by different authors (e.g. Nei, 1975; Sbordoni et al., 1980; Thorpe, 1982; Bert, 1986).

\section{Genetic differentiation and estimated levels of gene flow}

Populations of G. gauthieri and G. ibericus are highly subdivided at many loci. Single locus $\theta$ values of one are no exception, and one may wonder if the samples examined are still to be considered conspecific. Significant population subdivision occurs at much higher levels than those recorded in cave-dwelling species (Caccone \& Sbordoni, 1987 ) or in related members of the $G$. pulex-group from central and southern France (Scheepmaker, 1990). Estimated levels of gene flow $\left(\mathrm{Nm}^{*}, \mathrm{Nm}\right.$ and $N m_{\theta}$ ) in sets, subsets, or pairwise combinations of populations are in all but one case (G. gauthieri from stations 10-11) much smaller than one. This is in contrast with results of Scheepmaker (1990), who found occasionally high $\mathrm{Nm}^{*}, \mathrm{Nm}$ and $\mathrm{Nm}_{\theta^{-}}$ levels in population subsets and pairwise combinations. As pointed out by Scheepmaker $(1987,1990)$, periodic desiccation of riverbeds and erosion by heavy rainfall may be the acting force of population fragmentation and consequent stochastic processes in the Mediterranean area. The degree of temporary isolation of population fragments subjected to genetic drift increases with the xerothermic index (Bagnouls \& Gaussen, 1953; Scheepmaker, 1987) and the length of the dry season.

The xerothermic index of the stations sampled for this study ranges from about 70 (Malaga) to 93 (Amizmiz, $7 \mathrm{~km}$ from station 5 and $30 \mathrm{~km}$ from Marrakech). However, sampling areas are often separated by areas with a much higher xerothermic index; in Marrakech for instance, this value is 178 , and 118 in Fès (Fig. 1A, near area D). The mean length of the dry season is 7 months in Marrakech (Bagnouls \& Gaussen, 1953); in periods of drought this may be much longer. The consequent semipermanent desiccation of riverbeds and watercourses may result in long-term isolation of populations and increased levels of genetic divergence. During the Pliocene-Pleistocene sequence of cold phases similar dry conditions resulting in population subdivision may have prevailed (Scheepmaker et al., 1988), whereas intermittently more temperate pluvious conditions during the Pleistocene interglacials (Biberson, 1970) possibly allowed range extension.

\section{Cross-breeding experiments}

In cross-breeding experiments, inter-continental $G$. gauthieri populations from stations 6,10 and $b$ $(D=0.41-0.53)$ suggest partial intersterility; F2 was never obtained. However, negative results may be due to unfavourable laboratory conditions; Scheepmaker et al. (1988) obtained F2 juveniles in one of the reciprocal crosses between genetically more distant $G$. gauthieri samples $(D=0.60)$. Moreover, in inter-specific inter-continental crosses between $G$. gauthieri and $G$. ibericus from stations 6 and $\mathrm{g}(D=0.82)$, one of the reciprocal crosses yielded F2 offspring. These results agree with findings of Scheepmaker et al. (1988), and corroborate their opinion that cross-breeding experiments are not conclusive in attempts to resolve the taxonomic status of Iberian members of the $G$. pulex-group.

The results of the cross-breeding experiments 
(i.e. at least partial interfertility among genetically distant population samples) suggest that, although important differences occur in structural genes coding for enzymes, regulatory genes may still be compatible to a high degree. Most regulatory genes are active during the ontogenetic process. To complete this process, compatibility of regulatory genes is required (Dubois, 1983). The conservatism of regulatory genes is supported by the morphological homogeneity among genetically distant populations of $G$. gauthieri (and, to some extent, $G$. ibericus).

\section{Acknowledgements}

I am indebted to Prof. Dr. Steph Menken, Dr. Sjouk Pinkster and Prof. Dr. Jan Stock for commenting on the manuscript; to Drs. Florence Pieters for correcting with hawk eyes the final draft of the manuscript and for many substantial comments on it; to Dr. C.F. Boutin (who showed us to locality 5 in the High Atlas) and to Dr. Sjouk Pinkster (who did extensive sampling in Morocco 20 years ago) for valuable information on sampling localities; to Dr. Sjouk Pinkster and Drs. Jan van Dalfsen for their assistance in the field, and to Bart van den Hoek for his help in running the cross-breeding experiments. This study was supported by grant R85-211 from the Netherlands Organization for the Advancement of Pure Research (N.W.O.).

\section{References}

Ager, D.V., 1980. The geology of Europe: i-xix, 1-535 (McGraw-Hill, London etc.)

Ayala, F.J. \& J.R. Powell, 1972. Allozymes as diagnostic characters of sibling species of Drosophila. Proc. natn. Acad. Sci. USA, 69(5): 1094-1096.

Bagnouls, F. \& H. Gaussen, 1953. Saison sèche et indice xérothermique. Bull. Soc. Hist. nat. Toulouse, 88: 193-239.

Barton, N.H. \& M. Slatkin, 1987. A quasi equilibrium theory of the distribution of rare alleles in a subdivided population. Heredity, 56: 409-415.

Bert, T.M., 1986. Speciation in western Atlantic stone crabs (genus Menippe); the role of geological processes and climatic events in the formation and distribution of species. Mar. Biol., 93: 157-170.
Biberson, P., 1970. The problem of correlations between South Europe and North Africa during the Pleistocene. Palaeogeography, Palaeoclimatology, Palaeoecology, 8: 113-127.

Busack, S.D., 1986. Biogeographic analysis of the herpetofauna separated by the formation of the Strait of Gibraltar. Natn. geogr. Research, 2 (1): 17-36.

Caccone, A. \& V. Sbordoni, 1987. Molecular evolutionary divergence of North American cave crickets. I. Allozyme variation. Evolution, 41 (6): 1198-1214.

Dercourt, J., L.P. Zonenshain, L.E. Ricou, V.G. Kazmin, X. Le Pichon, A.L. Knipper, C. Grandjacquet, I.M. Sborshchikov, J. Boulin, O. Sorokhtin, J. Geyssant, C. Lepvrier, B. Biju-Duval, J.C. Sibuet, L.A. Savostin, M. Westphal \& J.P. Lauer, 1985. Présentation de 9 cartes paléogéographiques au 1-2.000.000 s'étendant de l'Atlantique au Pamir pour la période du Lias à l'actuel. Bull. Soc. geol. France, 8,1(5): 637-652; 10 cartes en couleurs hors texte.

Dubois, A., 1983. Hybridation interspécifique, similarité génétique, parenté phylogénétique et classification supraspécifique en zoologie. Ann. Biol., 22(1): 37-68.

Ellis, W.N., 1987. Jelly version 1.06; a program for the Macintosh computer for the generation of Wagner character state networks using allele frequency characters (available free of charge from the author, c/o Institute of Taxonomic Zoology, Entomology Department, Plantage Middenlaan 64, 1018 DH Amsterdam).

Ellis, W.N., 1989. Thèta version 1.01; a program for the Macintosh computer for the analysis of population structure and the estimation of gene flow levels based on the method of Weir and Cockerham, 1984 (available free of charge from the author, c/o Institute of Taxonomic Zoology, Entomology Department, Plantage Middenlaan 64, 1018 DH Amsterdam).

Farris, J.S., 1972. Estimating phylogenetic trees from distance matrices. Am. Natural., 106: 645-668.

Farris, J.S., 1981. Distance data in phylogenetic analysis. In: V.A.\& D.R. Brooks, eds. Advances in cladistics: Proceedings of the first meeting of the Willi Hennig Society, 3-23 (New York Botanical Garden, Bronx).

Gledhill, T., D.W. Sutcliffe \& W.D. Williams, 1976. Key to the British freshwater Crustacea: Malacostraca. Sci. Publ. Brit. freshw. Ass., 32: 1-71.

Golikov, A.N.\& N.L. Tzvetkova, 1972. The ecological principle of evolutionary reconstruction as illustrated by marine animals. Mar. Biol., 14(1): 1-9.

Hsü, K.J., L. Montadert, D. Bernouilli, M.B. Cita, A. Erickson, R.E. Garrison, R.B. Kidd, F. Mèlierés, C. Müller \& R. Wright, 1977. History of the Mediterranean salinity crisis. Nature, 267: 399-403.

Hynes, H.B.N., 1954. The ecology of Gammarus duebeni Liljeborg and its occurrence in fresh water in western Britain. $J$. anim. Ecol., 23: 38-84.

Hynes, H.B.N., 1955. Distribution of some freshwater amphipods in Britain. Verh. int. Ver. theor. angew. Limnol., 12: 620-628.

Karaman, G.S. \& S. Pinkster, 1977. Freshwater Gammarus spe- 
cies from Europe, North Africa and adjacent regions of Asia (Crustacea-Amphipoda). Part 1. Gammarus pulex-group and related species. Bijdr. Dierk., 47(1): 1-97.

Lincoln, R.J., 1979. British marine Amphipoda: 1-647 (British Museum, London).

Lop, A.F., 1987. Anàlisis de la variabilidad intra e interspecifica en el grupo de Echinogammarus berilloni (Crustacea, Amphipoda): [i-xiv], 1-463, [1-10], pls. I-X (Tesis doctoral Universidad Complutense de Madrid).

Maldonado, A., 1985. Evolution of the Mediterranean basins and a detailed reconstruction of the cenozoic paleoceanography. In: R. Margalef, ed., Western Mediterranean: 17-59 (Pergamon Press, Oxford, etc.).

Nei, M., 1972. Genetic distance between populations. Am. Natural., 106: 283-292.

Nei, M., 1975. Molecular population genetics and evolution: 1-525 (North-Holland, Amsterdam).

Notenboom, J., 1988. Phylogenetic relationships and biogeography of the groundwater dwelling amphipod genus Pseudoniphargus (Crustacea), with emphasis on the Iberian species. Bijdr. Dierk., 58(2): 159-204.

Patton, J.C. \& J.C. Avise, 1983. An empirical evaluation of qualitative Hennigian analysis of protein electrophoretic data. J. mol. Evol., 19: 244-254.

Pinkster, S., 1971. Members of the Gammarus pulex-group (Crustacea-Amphipoda) from North Africa and Spain, with the description of a new species from Morocco. Bull. zoöl. Mus. Univ. Amsterdam, 2(7): 45-61.

Pinkster, S., 1983. The value of morphological characters in the taxonomy of Gammarus. Beaufortia, 33(2): 15-28.

Pinkster, S. \& D. Platvoet, 1986. De vlokreeften van het Nederlandse oppervlaktewater. Wetensch. Meded. Kon. Ned. natuurh. Ver., 172: 1-44.

Pinkster, S., A.L. Dennert, B. Stock \& J.H. Stock, 1970. The problem of European freshwater populations of Gammarus duebeni Liljeborg, 1852. Bijdr. Dierk., 40(2): 116-147.

Pomerol, Ch., 1973. Stratigraphie et paléogéographie de l'ère Cénozoique (Tertiaire et Quarternaire): 1-269 (Doin, Paris).

Rogers, J.S., 1984. Deriving phylogenetic trees from allele frequencies: a comparison of nine genetic distances. Syst. Zool., 35(3): 297-310.

Sbordoni, V., A. Caccone, E. De Matthaeis \& M. Cobolli Sbordoni, 1980. Biochemical divergence between cavernicolous and marine Sphaeromidae and the Mediterranean salinity crisis. Experientia, 36: 48-49.

Scheepmaker, M., 1987. Morphological and genetic differentia- tion of G. stupendus Pinkster, 1983 in the Massif de la Sainte Baume, France. Bijdr. Dierk., 57(1): 1-18.

Scheepmaker, M., 1990. Genetic differentiation and estimated levels of gene flow in members of the Gammarus pulex-group (Crustacea, Amphipoda) in western Europe. Bijdr. Dierk., 60(1): 3-29.

Scheepmaker, M. \& J. van Dalfsen, 1989. Genetic differentiation in Gammarus fossarum and G. caparti (Crustacea, Amphipoda) with reference to G. p. pulex in northwestern Europe. Bijdr. Dierk., 59(3): 127-139.

Scheepmaker, M., F. van der Meer \& S. Pinkster, 1988. Genetic differentiation of the Iberian amphipods Gammarus ibericus Margalef, 1951 and G. gauthieri S. Karaman, 1935, with reference to some related species in France. Bijdr. Dierk., 58(2): 205-226.

Skadsheim, A. \& H.R. Siegismund, 1986. Genetic relationships among north-western European Gammaridae (Amphipoda). Crustaceana, 51(2): 163-175.

Slatkin, M., 1981. Estimating levels of gene flow in natural populations. Genetics, 99: 323-335.

Slatkin, M., 1985. Rare alleles as indicators of gene flow. Evolution, 39: 53-65.

Sneath, P.H.A. \& R.R. Sokal, 1973. Numerical taxonomy: i-xv, 1-780 (W.H. Freeman and Company, San Francisco).

Stock, J.H., 1978. The non-marine gammarids of the Balearic Islands. Bol. Soc. Hist. nat. Baleares, 22: 17-47.

Stock, J.H. \& S. Pinkster, 1970. Irish and French freshwater populations of Gammarus duebeni subspecifically different from brackish water populations. Nature, 228: 874-875.

Swofford, D.L. \& R.B. Selander, 1981. Biosys-1. A computer program for the analysis of allelic variation in genetics. J. Heredity, 72: 281-283.

Thorpe, J., 1982. The molecular clock hypothesis: biochemical evolution, genetic differentiation and systematics. Annual Rev. Ecol. Syst., 13: 139-168.

Weir, B.S. \& C.C. Cockerham, 1984. Estimating F-statistics for the analysis of population structure. Evolution, 38(6): 1358-1370.

Workman, P.L. \& J.D. Niswander, 1970. Population studies on southwestern Indian tribes. II. Local genetic differentiation in the Papago. Amer. J. human Genet., 22: 24-49.

Wright, S., 1931. Evolution in Mendelian populations. Genetics, 16: 97-159.

Received: 31 July 1989

Revised: 12 January 1990 